\title{
A novel multi-enzyme preparation produced from Aspergillus niger using biodegradable waste: a possible option to combat heterogeneous biofilms
}

\author{
Arashdeep Kaur ${ }^{1}$, Valbha Rishi², Sanjeev Kumar Soni ${ }^{{ }^{*}}$ and Praveen Rishi ${ }^{{ }^{*}}$
}

\begin{abstract}
Extracellular polymeric substance (EPS) produced by the microorganisms provides protection and stability to them when they are encased within biofilms. Heterogeneous polysaccharides form a major constituent of the EPS and are crucial for the formation and integrity of the biofilms/slime. Thus, breakdown of polysaccharides might help in dispersion of biofilms from abiotic surfaces. In the present study we isolated a fungus, Aspergillus niger APS, capable of concurrently producing a cocktail of carbohydrases and optimized the conditions for higher yields of all the enzymes by one variable at a time (OVAT) approach. The optimization studies resulted in 1.5 to 12 fold augmentation in the enzyme yields using biodegradable waste. Further, keeping in view the heterogeneous nature of polysaccharides in biofilm matrix, the in-house produced enzyme cocktail was used for the dispersal of biofilms formed by Salmonella enterica serovar Typhi, Escherichia coli and Staphylococcus aureus. Treatment with enzyme preparation caused $90.23 \pm 4.0,82.64 \pm 5.0$ and $76.32 \pm 5.0 \%$ reduction of the biofilms formed by these organisms respectively which was also evidenced by Field emission scanning electron microscopy (FESEM) revealing the loss of biofilm architecture. Interestingly, the enzyme cocktail could also remove viscous slime formed under natural conditions in the kitchen drainage pipe (KDP). To the best of our knowledge, this is the first report on biotreatment of abiotic surfaces for removal of biofilms/slime formed under natural conditions. The study thus indicates the prospects of using multiple carbohydrases as an anti-biofouling agent on abiotic surfaces like equipments as well as implants/prostheses and pipelines.
\end{abstract}

Keywords: Aspergillus niger, Biofilm, Carbohydrases, Enzyme cocktail, Extracellular polymeric substance (EPS)

\section{Introduction}

Enzymes, also known as bio-catalysts, play an important role in the metabolism and other biochemical pathways in all living organisms including microorganisms, plants, and animals. Some of these bio-catalysts are of special interest and are exploited commercially for economical synthesis of numerous products on an industrial scale. Eco-friendly nature, low energy input

\footnotetext{
*Correspondence: sonisk@pu.ac.in; rishipraveen@yahoo.com

${ }^{1}$ Department of Microbiology, Panjab University, Chandigarh, India

Full list of author information is available at the end of the article
}

and cost-effectiveness of enzymes, as compared to their chemical counterparts, make them a better candidate for various processes (Nigam 2013). As compared to other sources like plants and animals, the production of enzymes from microorganisms is considered more economical, easier and faster than the plant and animal cells. Further, the enzyme production by microorganisms is neither influenced by climatic or seasonal changes, nor by regulatory or ethical issues. Easy downstream processing of microbial extracellular enzymes further makes them a superior choice (Tufvesson et al. 2010). For these
Springer Open

(C) The Author(s) 2020. This article is licensed under a Creative Commons Attribution 4.0 International License, which permits use, sharing, adaptation, distribution and reproduction in any medium or format, as long as you give appropriate credit to the original author(s) and the source, provide a link to the Creative Commons licence, and indicate if changes were made. The images or other third party material in this article are included in the article's Creative Commons licence, unless indicated otherwise in a credit line to the material. If material is not included in the article's Creative Commons licence and your intended use is not permitted by statutory regulation or exceeds the permitted use, you will need to obtain permission directly from the copyright holder. To view a copy of this licence, visit http://creativeco mmons.org/licenses/by/4.0/. 
reasons, most of the enzymes used in various industries are obtained from microbial sources.

Although a number of microorganisms have been isolated and studied for the production of different enzymes, however, looking at the huge natural biodiversity, bioprospecting helps in tapping the ecosystem for the isolation of novel sources of enzymes and other metabolites. A number of industries require cocktail of enzymes rather than a single enzyme e.g. biofuel production by hydrolysis of lignocellulosic biomass (Rana et al. 2013; Binod et al. 2019), biohydrogen production (Ye et al. 2009), bio-deinking (Singh et al. 2019), to enhance digestibility and nutrient availability of animal feed (Alsersy et al. 2015) and detergent industry (Naganthran et al. 2017). Considering the economic point, a single organism capable of elaborating multiple enzymes is preferred for such applications. In this regard, fungi are preferred over other microorganisms, since they produce a broad range of enzymes (Chugh et al. 2016). Additionally, cost-effective production using cheap substrates is an important prerequisite for industrial use/commercialization. In view of these concerns, we made attempts to design an economically viable medium for the concurrent production of multiple enzymes from a selected fungal isolate after executing the desired optimization, as the latter becomes mandatory before exploiting any agents for its applied value. The multiple enzymes so produced, were evaluated for their potential as anti-biofouling agent to disperse the biofilms of pathogenic bacteria as well as to clean the slime formed on drainage pipe which is considered to be a matrix having various substrates.

Biofilm formation is one of the most remarkable survival strategies adopted by bacteria, in natural and in clinical settings (Flemming et al. 2016). From human teeth to industrial sites, biofilms can form wherever there are sufficient water and nutrients (Costerton et al. 1995). One of the major concerns associated with microbial biofilm formation is, biofouling, a complex interaction between the membrane material, dissolved substances, fluid flow parameters and microbial biofilms. For example, thick layers of slime found on the inner surface of drainage pipes, commonly known as 'black gunk' (containing human wastes, food residues, oils, soap films, hair, decomposing materials) are a focal point for heterogeneous biofilms formed as a result of intra and interspecies interactions among the microorganisms. Within biofilms, the bacteria are encased within extracellular polymeric substances (EPS) which protects them from antimicrobial agents and also provides structural integrity to biofilms (Payne and Boles 2016; Wang et al. 2018; Zhang et al. 2019). The EPS consists of various biopolymers, out of which heterogeneous polysaccharides are one of the predominant components. Strategies making use of enzymes including individual (Loiselle and Anderson 2003, Nijland et al. 2010; Kalpana et al. 2012; Lamppa and Griswold 2013) as well as mixture of enzymes (Orgaz et al. 2006; Orgaz et al. 2007; Singh et al. 2015; Fleming, et al. 2017) have been investigated to combat biofilms. Lequette et al. (2010) analyzed the cleaning efficiency of different polysaccharidases and proteolytic enzymes against bacterial biofilms commonly found in the food industry processing lines. Efficacy of proteases and carbohydrases like cellulases, amylase and pectinase have also been evaluated against the biofilms of Pseudomonas sp., Bacillus subtilis and Staphylococcus aureus (Orgaz et al. 2007; Singh et al. 2015) which these organisms may form in the clinical settings as well as on medical devices. Therefore, keeping in view (i) the heterogeneity of the extracellular polysaccharides on the biofouled surfaces and, (ii) the cost incurred in procuring the purified enzyme preparations, a mixture of enzymes may be more beneficial for sufficient disruption of bacterial biofilms and clearing of slime. This study thus envisages the perspective of developing a cost-effective and eco-friendly process to obtain multiple carbohydrases, capable of disrupting biofilms formed in vitro as well as the slime formed on kitchen drainage pipe (KDP) under natural conditions.

\section{Materials and methods}

\section{Isolation of the fungal strain}

A natural variant of the fungal strain belonging to genus Aspergillus niger was used in the present study. The strain capable of producing the required enzyme cocktail was isolated from the soil after screening various samples in the form of rotten foods, decomposed kitchen waste, decaying agricultural residues and soil collected aseptically from various places in and around Chandigarh, India. The isolates were screened for production of extracellular enzymes namely cellulases, hemicellulases, pectinase, amylases and alginate lyase enzymes by substrate hydrolysis method.

\section{Identification of the strain}

The strain was identified to the genus level on the basis of macroscopic and microscopic features while the complete taxonomic status was established by $18 \mathrm{~S}$ ribosomal sequencing taking the services of Eurofins Genomics, India. The phylogenetic tree was generated using the Maximum Likelihood method (Kimura 1980).

\section{Selection of suitable fermentation technique for the production of enzyme cocktail}

To find out the choicest method for the production of an extracellular cocktail of carbohydrases from the isolated strain; surface, submerged and solid-state fermentation methods were tried. For surface and submerged 
fermentation, the media contained wheat bran (2\%), yeast extract $(0.25 \%)$ and peptone $(0.25 \%)$. For solid-state fermentation $5 \mathrm{~g}$ wheat bran $(50 \%)$, yeast extract $(0.25 \%)$ and peptone $(0.25 \%)$ moistened with $5 \mathrm{ml}$ distilled water was used. These media were sterilized by autoclaving at 15 psi for 20 min, inoculated with five discs cut from the periphery of actively growing culture of fungal strain Aspergillus niger APS grown on potato dextrose agar (PDA) plates and incubated for 4 days. For submerged fermentation, incubation was done under shaking conditions (150 rpm) at $30{ }^{\circ} \mathrm{C}$ while for surface and solidstate fermentation, incubation was done under static conditions at $30{ }^{\circ} \mathrm{C}$. After incubation, $100 \mathrm{ml}$ distilled water was added to the flask of solid-state fermentation and kept for shaking for one hour at $30{ }^{\circ} \mathrm{C}$. The contents of all the flasks were filtered through a sieve. Filtrates so obtained were centrifuged at $10,000 \mathrm{rpm}$ at $4{ }^{\circ} \mathrm{C}$ for $15 \mathrm{~min}$ and the clear supernatants were used as the sources of extracellular enzymes.

\section{Enzyme assays}

Cellulase (CMCase, FPase and $\beta$-1,4-glucosidase), hemicellulase (xylanase and mannanase), pectinase and glucoamylase activities in cell free supernatants were assayed by quantification of reducing sugars liberated by these enzymes from respective substrates followed by estimation by the 3,5-dinitrosalicylic acid (DNS) method (Miller 1959). The activities of enzymes were expressed in International Units (IU) where one unit each of the CMCase, FPase, $\beta$-glucosidase, xylanase, mannanase, pectinase and glucoamylase is equivalent to the enzyme that releases one $\mu$ mole of end product in one min under standard assay conditions. $\alpha$-amylase assay was performed by the method of Fuwa (1954) wherein one IU is equivalent to the amount of enzyme which reduces the color of starch-iodine complex by $10 \%$ in $10 \mathrm{~min}$. In the case of alginate lyase, one unit has been defined as an increase in optical density $(235 \mathrm{~nm})$ of 0.010 per $\mathrm{min}$ (Sawabe et al. 1992).

\section{Time course studies for the production of multiple carbohydrases from the selected fungus}

The time course for the production of all the carbohydrases i.e. cellulases, hemicellulases, pectinase, amylases, and alginate lyase, on wheat bran was studied by preparing different sets of $250 \mathrm{ml}$ Erlenmeyer flasks and carrying out the surface fermentation under static conditions and submerged fermentation for 10 days at $30{ }^{\circ} \mathrm{C}$. The production profiles of all the carbohydrases was studied by withdrawing flasks, in duplicate, at regular intervals of
$24 \mathrm{~h}$ and the enzyme yields were determined as discussed above.

\section{Standardization of cultural and environmental conditions for optimization of co-production of various enzymes under surface culture fermentation}

This study was attempted by assessing the effect of various carbon, nitrogen and mineral sources in the production medium as well as the effect of incubation temperature and $\mathrm{pH}$ of the medium in surface culture fermentation under static conditions for 6 days at $30{ }^{\circ} \mathrm{C}$, unless otherwise stated. The working volume of the fermentation was $50 \mathrm{ml}$ and fermentation was carried out in $250 \mathrm{ml}$ Erlenmeyer flask.

\section{Effect of carbon sources}

The effect of various carbon sources was studied by replacing wheat bran in the production medium with either of the cellulose, carboxymethyl cellulose, guar gum, pectin, starch, cellobiose, lactose, glucose, galactose, salicin, xylose at a concentration of $1 \%$ while concentration of de-oiled rice bran and kitchen waste (dried in hot air oven at $70{ }^{\circ} \mathrm{C}$ and crushed to powder form) was kept $2.0 \%$. Medium containing wheat bran was used as control.

\section{Effect of various metal ions}

Effect of various metal ions was studied by supplementing the medium with different metal salts including $\mathrm{CaSO}_{4}, \mathrm{ZnCl}_{2}, \mathrm{~K}_{2} \mathrm{HPO}_{4}, \mathrm{FeSO}_{4}, \mathrm{MnSO}_{4}, \mathrm{MgSO}_{4}$, $\mathrm{KH}_{2} \mathrm{PO}_{4}$, and $\mathrm{KCl}$, separately, at a concentration of $0.02 \%$. Medium without supplementation of any metal salt was used as control.

\section{Effect of nitrogen source}

The effect of nitrogen was studied by replacing peptone and yeast extract with various inorganic nitrogen sources including $\left(\mathrm{NH}_{4}\right)_{2} \mathrm{SO}_{4}, \mathrm{NH}_{4} \mathrm{Cl}, \mathrm{NaNO}_{3}$ and organic nitrogen sources including urea, yeast extract, mycological peptone, tryptone and corn steep liquor (CSL), keeping the final concentration of all the sources at $0.5 \% \mathrm{w} / \mathrm{v}$. Medium without supplementation of any nitrogen source was used as control.

\section{Effect of incubation temperature}

The effect of temperature was studied by incubating the flasks at different temperatures including $20^{\circ}, 25^{\circ} 30^{\circ}$, $35^{\circ}, 40^{\circ}$ and $50^{\circ} \mathrm{C}$ 


\section{Effect of initial $\mathrm{pH}$ of the medium}

This was studied by adjusting the initial $\mathrm{pH}$ of the production medium at 2.0, 3.0, 4.0, 5.0, 6.0, 7.0, 8.0, 9.0 and 10.0 by the addition of $\mathrm{HCl}(1 \mathrm{~N})$ or $\mathrm{NaOH}(1 \mathrm{~N})$.

\section{Bacterial strains for biofilm formation}

The bacteria used for biofilm production were Salmonella enterica serovar Typhi Ty2 (S. Typhi) (initially procured from Central Research Institute, Kasauli, India), Staphylococcus aureus ATCC 9144 and Escherichia coli MTCC 3222 (procured from IMTECH, Chandigarh, India).

\section{Quantification of biofilm formation by microtitre plate method}

Quantification of biofilm formation was carried out in sterile polystyrene microplates by the method described by Stepanović et al. (2000). Briefly, the wells of a sterile polystyrene microplate were filled with $230 \mu \mathrm{l}$ of medium. A quantity of $20 \mu \mathrm{l}$ of overnight grown culture (cell count adjusted to $10^{8} \mathrm{CFU} / \mathrm{ml}$ ) was added into each well. The plates were incubated for $24 \mathrm{~h}$ at $37^{\circ} \mathrm{C}$. The contents of the plate were poured off and washed three times with $250 \mu \mathrm{l}$ of phosphate buffer saline (PBS; $0.01 \mathrm{M}, \mathrm{pH} 7.0$ ). The biofilms were fixed with $250 \mu \mathrm{l}$ of methanol per well. After $15 \mathrm{~min}$, microplates were emptied and air-dried. Thereafter, microplates were stained with $250 \mu \mathrm{l}$ per well of crystal violet for $10 \mathrm{~min}$. Excess stain was rinsed off with sterile distilled water. The plates were air-dried, the dye bound to the adherent cells was resolubilized with $250 \mu \mathrm{l}$ of $33 \%$ (v/v) glacial acetic acid per well and optical densities were read at $595 \mathrm{~nm}$ in a microplate reader. The negative control wells contained broth only.

\section{Standardization of biofilm formation}

Biofilm formation by the selected pathogens was standardized in microtitre plates by varying the media (Luria broth (LB), brain heart infusion (BHI) broth and tryptic soy broth (TSB) for biofilm formation. The effect of incubation period on biofilm formation was also standardized by incubating and quantifying the biofilm formation after every $24 \mathrm{~h}$ for a period of 5 days.

\section{Biofilm removal efficiency of the enzyme cocktail produced by $A$. niger APS}

To check the biofilms dispersal efficacy of the enzyme cocktail, the biofilms were developed on microtitre plates as described above. After biofilm development, the non-adherent cells were removed by washing with PBS. After washing, $250 \mu \mathrm{l}$ of the enzyme preparation (filter sterilized) was added to the wells followed by incubation at $37^{\circ} \mathrm{C}$ for $1 \mathrm{~h}$. The in-house produced enzyme cocktail comprised multiple carbohydrases including CMCase $(3.8 \mathrm{IU} / \mathrm{ml})$, FPase $(1.22 \mathrm{IU} / \mathrm{ml})$, $\beta$-glucosidase $(3.68 \mathrm{IU} / \mathrm{ml})$, pectinase $(14.2 \mathrm{IU} / \mathrm{ml})$, xylanase $(40 \mathrm{IU} / \mathrm{ml})$, mannanase $(7.4 \mathrm{IU} / \mathrm{ml})$, glucoamylase $(41.0 \mathrm{IU} / \mathrm{ml}), \alpha$-amylase $(2760 \mathrm{IU} / \mathrm{ml})$ and alginate lyase $(3.3 \mathrm{IU} / \mathrm{ml})$. Wells with biofilms and without any enzymatic treatment served as control. Heat-inactivated enzymes were also run in parallel. The biofilm removal efficiency of the enzyme cocktail was evaluated by percentage reduction method described by Pitts et al. (2003). Percentage reduction was calculated by the following formula:

$$
\begin{aligned}
& \text { Percentage reduction } \\
& \quad=[(\mathrm{C}-\mathrm{B})-(\mathrm{T}-\mathrm{B}) /(\mathrm{C}-\mathrm{B})] \times 100 \%
\end{aligned}
$$

where $\mathrm{B}$ denotes the average absorbance per well for blank (no biofilm, no treatment); $\mathrm{C}$ denotes the average absorbance per well for control wells (biofilms, no treatment); $\mathrm{T}$ denotes the average absorbance per well for treated wells (biofilm and treatment). The disruption of the biofilms was also checked by field emission scanning electron microscopy (FESEM).

\section{Field emission scanning electron microscopy (FESEM)}

For FESEM, biofilms were grown by immersing the coverslips in the wells of a 6-well polystyrene plate. After biofilm formation, the coverslips were washed with phosphate buffer saline to remove the planktonic cells. To visualize the effect of enzymes, the biofilms developed on coverslips were incubated with the enzyme cocktail (filter sterilized) for $30 \mathrm{~min}$. The control biofilms were incubated with PBS for $30 \mathrm{~min}$. Thereafter, the biofilms on the coverslip were fixed with $2.5 \%$ glutaraldehyde for $1 \mathrm{~h}$. The glutaraldehyde was washed off thrice with $0.1 \mathrm{M} \mathrm{PBS}(\mathrm{pH}$ 7.2). After this, gradual dehydration was carried out by incubating the coverslips with increasing concentration of ethanol (30-90\%), for about $15 \mathrm{~min}$ in each gradient. Final dehydration was done with $100 \%$ ethanol at room temperature and the dehydrated samples were dried, gold-sputtered and examined under Field Emission Scanning Electron Microscope (SU8010, Hitachi).

\section{Removal of slime formed on kitchen drainage pipe (KDP) under natural conditions}

A piece of KDP with preformed thick slime layer was cut carefully. The piece was divided into four parts to be used as (i) control (no treatment) (ii) piece treated with phosphate buffer saline (0.05 M; pH 7.0) (iii) piece treated with enzyme cocktail and (iv) piece treated with heat inactivated enzymes. The effect of PBS, enzyme cocktail and heat inactivated enzyme cocktail was studied by immersing the KDP pieces in the respective solutions at 
room temperature. The effect was visualised after $2 \mathrm{~h}$, $24 \mathrm{~h}$ and $48 \mathrm{~h}$ of incubation by visualizing the KDP pieces for the dispersal of slime layer, if any. The slime dispersed by the action of multiple carbohydrases was separated from KDP by washing with PBS and erosion of the slime was compared to other treatments.

\section{Statistical analysis}

The data are expressed as mean \pm standard deviation. Statistical significance between various groups was evaluated using one way analysis of variants (ANOVA) followed by Dunnett's multiple comparison tests. In all data analysis, $\mathrm{p}$-values of 0.001 or less $(\mathrm{p} \leq 0.001)$ were considered significant.

\section{Accession number and availability of the strain}

The isolated strain, designated as Aspergillus niger APS was deposited in general collection of Microbial Type Culture Collection (MTCC) under the accession number 12975.The $18 \mathrm{~S}$ rRNA gene sequence $(600 \mathrm{bp})$ of the strain was deposited in the GenBank with accession number MN559364.

\section{Results}

\section{Isolation of the microorganism}

After extensive screening of various samples, 38 isolates were selected during primary screening, out of which, 21 isolates were selected (on the basis of the clear zone size) and were subjected to secondary screening by growing them as submerged cultures on wheat bran based media (data not shown). A soil isolate S-34 capable of producing a cocktail of carbohydrases (cellulases, xylanase, mannanase, pectinase, amylases, and alginate lyase) in appreciable amounts, using wheat bran as substrate, was selected.

\section{Identification of the strain}

Macroscopic and microscopic analysis: The isolated strain grew rapidly on Saboraud Dextrose Agar, the growth occurred as a mat which was initially white to yellowish in appearance and turned black as the conidia formed during further incubation. Microscopic examination performed using lactophenol cotton blue staining revealed septate and hyaline hyphae. Long conidiophores with brown to black conidia were also observed.

Molecular analysis: 18S rDNA sequencing of the isolated fungal strain S-34 revealed 600 bp sequence and was found to share high similarity with the species of genus Aspergillus. The ITS region sequence was used to carry out BLAST with the database of NCBI Genbank. Phylogenetic analysis revealed that the isolated strain was closely related to Aspergillus niger and was named as $A$. niger APS.

Enzyme production by different fermentation techniques Out of the different fermentation techniques tried, maximum enzyme productions were observed under surface fermentation followed by submerged fermentation and solid state fermentation respectively. Maximum CMCase $(2.16 \pm 0.03 \mathrm{IU} / \mathrm{ml})$, FPase $(0.284 \pm 0.015 \mathrm{IU} / \mathrm{ml})$, mannanase $(3.96 \pm 0.014 \mathrm{IU} / \mathrm{ml})$, xylanase $(42.83 \pm 0.84 \mathrm{IU} /$ $\mathrm{ml}), \alpha$-amylase $(237.14 \pm 7.12 \mathrm{IU} / \mathrm{ml})$ and alginate lyase $(2.03 \pm 0.04 \mathrm{IU} / \mathrm{ml})$ yields were achieved under surface fermentation. In contrast, pectinase and glucoamylase productivities were higher under submerged fermentation while $\beta$-glucosidase $(2.6 \pm 0.013 \mathrm{IU} / \mathrm{ml})$ yields were optimal under solid state fermentation. Further, time course studies were performed under both the surface and submerged fermentations techniques in order to achieve maximal enzyme production.

Time-course studies for co-production of various enzymes Production of most of the enzymes started as early as $24 \mathrm{~h}$ of incubation however, FPase and alginate lyase production started after $48 \mathrm{~h}$ and $72 \mathrm{~h}$ respectively (Fig. 1). Maximum CMCase $(2.58 \pm 0.027 \mathrm{IU} / \mathrm{ml}), \beta$-glucosidase $(1.98 \pm 0.037 \mathrm{IU} / \mathrm{ml})$, pectinase $(5.48 \pm 0.12 \mathrm{IU} / \mathrm{ml})$, alginate lyase $(2.42 \pm 0.067 \mathrm{IU} / \mathrm{ml})$ and glucoamylase $(36.42 \pm 0.28 \mathrm{IU} / \mathrm{ml})$ activities were achieved after 6 days of incubation. On the other hand highest activities of mannanase $(3.46 \pm 0.082 \mathrm{IU} / \mathrm{ml})$ and xylanase $(43.33 \pm 0.182 \mathrm{IU} / \mathrm{ml})$ were achieved after 4 days while the maximum FPase $(0.775 \pm 0.013 \mathrm{IU} / \mathrm{ml})$ and $\alpha$-amylase $(1681 \pm 12.47 \mathrm{IU} / \mathrm{ml})$ yields were achieved after 8 and 7 days of incubation respectively. Although different enzyme components were produced maximally at different incubation times, 6 days of incubation was chosen for further studies, as this time period gave appreciable yields of all the enzymes with least compromises. A similar trend was observed in submerged fermentation (Additional file 1: Fig. S1) wherein optimal enzyme activities were observed after different time intervals. However, in comparison to surface fermentation, maximal enzyme levels were achieved after a longer incubation period under submerged fermentation.

\section{Standardization of cultural and environmental conditions Effect of carbon sources}

Various carbon sources listed in Table 1 were selected to study their effect on co-production of various enzyme components in the cocktail. Maximum yields of FPase $(1.24 \pm 0.02 \mathrm{IU} / \mathrm{ml})$, pectinase $(8.52 \pm 0.021 \mathrm{IU} / \mathrm{ml})$, glucoamylase $(42.67 \pm 2.25 \mathrm{IU} /$ $\mathrm{ml}), \alpha$-amylase $(2651.6 \pm 31.23 \mathrm{IU} / \mathrm{ml})$ and alginate lyase 

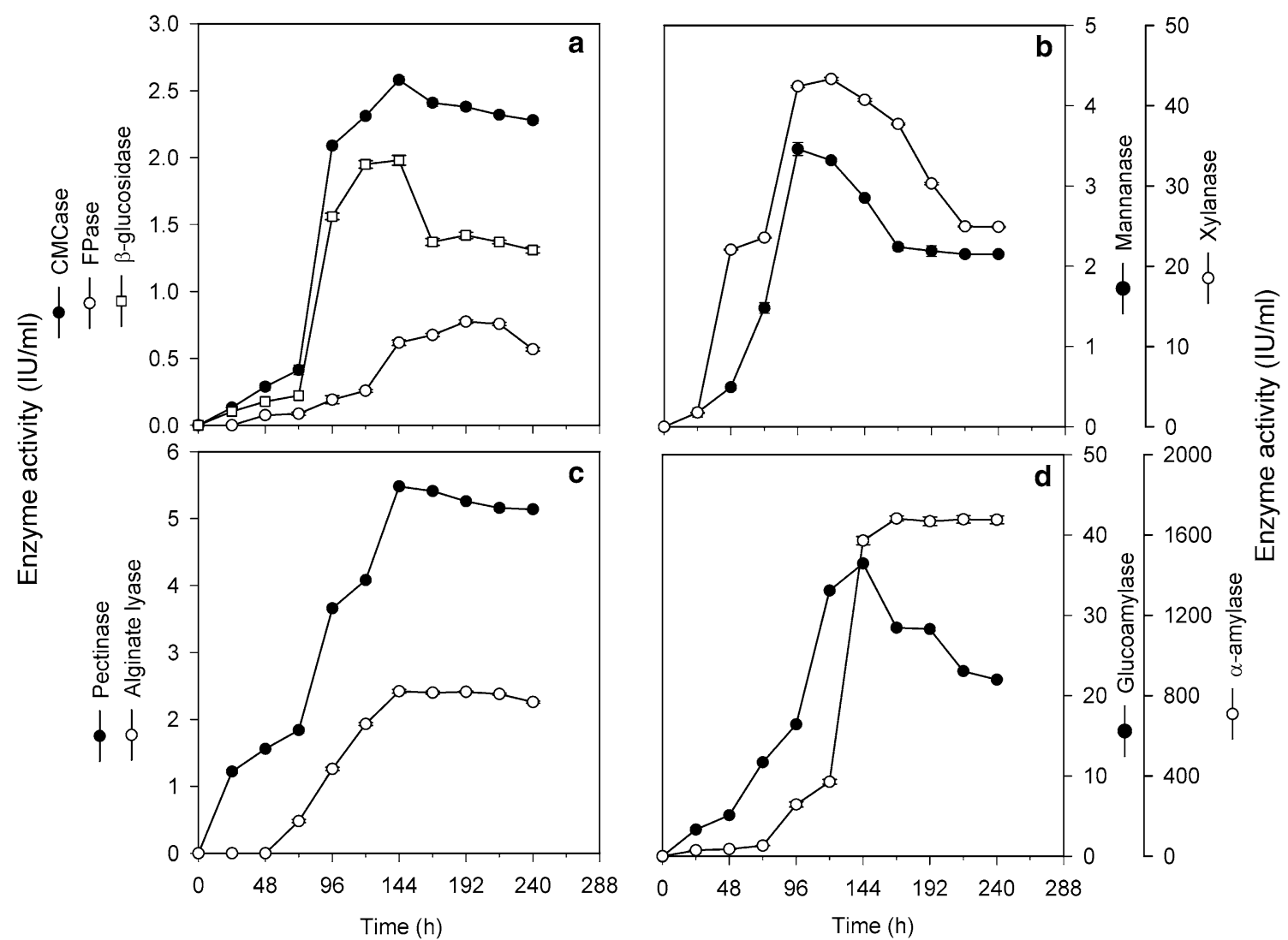

Fig. 1 Time course for co-production of different enzymes a cellulases; $\mathbf{b}$ hemicellulases; $\mathbf{c}$ pectinase and alginate lyase; $\mathbf{d}$ amylases; over a period of 10 days (240 h) under surface fermentation

$(3.02 \pm 0.014 \mathrm{IU} / \mathrm{ml})$ were achieved when kitchen waste was used as the carbon source and maximum CMCase $(2.27 \pm 0.02 \mathrm{IU} / \mathrm{ml})$ and xylanase $(39.05 \pm 0.44 \mathrm{IU} / \mathrm{ml})$ productivities were observed with wheat bran. Highest $\beta$-glucosidase $(1.77 \pm 0.014 \mathrm{IU} / \mathrm{ml})$ and mannanase $(5.83 \pm 0.021 \mathrm{IU} / \mathrm{ml})$ activities were observed in presence of guargum. Since, wheat bran and kitchen waste were found to give optimal yields of the enzymes, therefore, these two carbon sources were further tried in combination and a further increment in the enzyme productivities was observed.

\section{Effect of various metal ions}

Table 1 shows the effect of supplementation of various metal ions on the enzyme yields. Out of the various metal ions used, $\mathrm{CaSO}_{4}$ and $\mathrm{MgSO}_{4}$ led to a significant increase in the activities of pectinase, mannanase and xylanase as compared to the control while there was no significant effect on the yields of cellulases, amylases and alginate lyase. In contrast, supplementation of
$\mathrm{MnSO}_{4}, \mathrm{ZnCl}_{2}$ and $\mathrm{KCl}$ led to a significant decrease in the yields of cellulases, amylases, xylanase and alginate lyase.

\section{Effect of various nitrogen sources}

Various nitrogen sources including inorganic and organic (Table 1) were selected to study their effect on co-production of various enzyme components in the cocktail. Among the various inorganic and organic nitrogen sources tried, CSL was found to have significant effect on the yields of cellulases, pectinase and mannanase while no significant change in the yields of xylanase, glucoamylase and alginate lyase was observed. Maximum $\alpha$-amylase yield was recorded with ammonium chloride followed by ammonium sulphate and soyabean meal. Other nitrogen sources led to a decrease in the yields of most of the enzymes in the cocktail. CSL was chosen as the nitrogen source for further studies as it led to an appreciable increase in the activities of enzymes with least compromises. 
Table 1 Effect of various nutritional factors on co-production of various enzymes by A. niger APS

\begin{tabular}{|c|c|c|c|c|c|c|c|c|c|}
\hline $\begin{array}{l}\text { Nutritional } \\
\text { factors } \\
\text { Carbon Source }\end{array}$ & Enzyme activit & $y(I U / m l)$ & $\beta$-Glucosidase & Pectinase & Mannanase & Xylanase & $\begin{array}{l}\text { Gluco- } \\
\text { amylase }\end{array}$ & a-Amylase & $\begin{array}{l}\text { Alginate } \\
\text { lyase }\end{array}$ \\
\hline $\begin{array}{l}\text { De-oiled rice } \\
\text { bran }\end{array}$ & $1.76 \pm 0.03^{*}$ & $0.687 \pm 0.015^{*}$ & $0.535 \pm 0.023$ & $4.11 \pm 0.07$ & $2.31 \pm 0.012$ & $19.76 \pm 0.105$ & $27.43 \pm 1.42$ & $1228 \pm 19.2$ & 0.0 \\
\hline Kitchen waste & $1.08 \pm 0.01$ & $1.24 \pm 0.02$ & $1.02 \pm 0.02$ & $8.52 \pm 0.021$ & $1.45 \pm 0.012$ & $19.04 \pm 0.25$ & $42.67 \pm 2.25^{*}$ & $2652 \pm 31.23$ & $3.02 \pm 0.014$ \\
\hline Cellulose & $1.68 \pm 0.03$ & $0.472 \pm 0.02$ & $0.228 \pm 0.02$ & $2.47 \pm 0.015$ & 0.0 & 0.0 & $28.26 \pm 0.74$ & $1160 \pm 26.87$ & 0.0 \\
\hline CMC & $1.88 \pm 0.04^{*}$ & $0.811 \pm 0.02$ & $0.647 \pm 0.01$ & $2.56 \pm 0.03$ & $2.3 \pm 0.14$ & $2.4 \pm 0.081$ & $31.23 \pm 0.032$ & $1748 \pm 18.2$ & 0.0 \\
\hline Guargum & $1.72 \pm 0.04$ & $0.604 \pm 0.01$ & $1.77 \pm 0.018$ & $4.01 \pm 0.017$ & $5.83 \pm 0.021$ & 0.0 & $23.43 \pm 0.76$ & $1906 \pm 24.56$ & $0.87 \pm 0.03$ \\
\hline Pectin & $1.70 \pm 0.014$ & $1.14 \pm 0.014$ & $0.849 \pm 0.03$ & $5.8 \pm 0.012$ & $4.5 \pm 0.018$ & 0.0 & $29.87 \pm 1.06$ & $1416 \pm 21.46$ & $0.834 \pm 0.04$ \\
\hline Cellobiose & $1.37 \pm 0.012$ & $0.803 \pm 0.02$ & $0.122 \pm .017$ & $2.79 \pm 0.024$ & $0.43 \pm 0.015$ & 0.0 & $28.28 \pm 2.26$ & $1763 \pm 28.26$ & $0.962 \pm 0.06$ \\
\hline Lactose & $1.40 \pm 0.04$ & $0.846 \pm 0.02$ & $0.080 \pm 0.017$ & $2.38 \pm 0.014$ & $0.152 \pm 0.021$ & 0.0 & $27.25 \pm 1.12$ & $1461 \pm 23.52$ & $1.26 \pm 0.07$ \\
\hline Glucose & $1.32 \pm 0.014$ & $0.393 \pm 0.02$ & $0.251 \pm 0.02$ & $3.17 \pm 0.017$ & $0.501 \pm 0.011$ & 0.0 & $20.53 \pm 0.98$ & $2011 \pm 38.26$ & $2.34 \pm 0.11^{*}$ \\
\hline Galactose & $1.14 \pm 0.04$ & $0.219 \pm 0.02$ & $0.108 \pm 0.014$ & $2.32 \pm 0.023$ & $0.156 \pm 0.012$ & 0.0 & $27.48 \pm 1.37$ & $2139 \pm 41.34$ & $2.16 \pm 0.08^{*}$ \\
\hline Starch & $1.49 \pm 0.015$ & $0.994 \pm 0.01$ & $0.370 \pm .011$ & $3.67 \pm 0.024$ & $0.654 \pm 0.018$ & $1.43 \pm 0.09$ & $41.48 \pm 3.26^{*}$ & $2659 \pm 36.54$ & 0.0 \\
\hline Salicin & $0.89 \pm 0.01$ & $0.370 \pm 0.05$ & $0.108 \pm 0.06$ & $2.47 \pm 0.013$ & 0.0 & 0.0 & $4.56 \pm 0.042$ & $294 \pm 6.43$ & 0.0 \\
\hline Xylose & $1.53 \pm 0.032$ & $0.678 \pm 0.02^{*}$ & $0.939 \pm 0.017$ & $3.98 \pm 0.014$ & $0.686 \pm 0.08$ & $30.59 \pm 1.24$ & $18.42 \pm 1.02$ & $1288 \pm 16.37$ & $0.926 \pm 0.03$ \\
\hline $\begin{array}{l}\text { Wheat } \\
\text { bran + kitchen } \\
\text { waste }\end{array}$ & $2.61 \pm 0.021$ & $1.32 \pm 0.013$ & $2.48 \pm 0.026$ & $8.36 \pm 0.024$ & $3.42 \pm 0.036$ & $40.26 \pm 0.47$ & $41.33 \pm 0.56$ & $2632 \pm 33.0$ & $3.12 \pm 0.04$ \\
\hline $\begin{array}{l}\text { Control (Wheat } \\
\text { bran) }\end{array}$ & $2.72 \pm 0.02$ & $0.683 \pm 0.06$ & $1.94 \pm 0.03$ & $5.54 \pm 0.24$ & $3.76 \pm 0.01$ & $39.05 \pm 0.44$ & $37.08 \pm 0.42$ & $1574 \pm 2.50$ & $2.16 \pm 0.02$ \\
\hline \multicolumn{10}{|l|}{ Metal ions } \\
\hline $\mathrm{CaSO}_{4}$ & $2.94 \pm 0.014$ & $1.47 \pm 0.017$ & $2.89 \pm 0.044^{\#}$ & $10.31 \pm 0.071^{\#}$ & $4.73 \pm 0.086$ & $43.93 \pm 1.02$ & $44.02 \pm 2.03$ & $2643 \pm 47$ & $3.42 \pm 0.046$ \\
\hline $\mathrm{MgSO}_{4}$ & $2.75 \pm 0.03$ & $1.61 \pm 0.022$ & $2.26 \pm 0.017$ & $11.26 \pm 0.34^{\#}$ & $6.09 \pm 0.11$ & $46.27 \pm 4.3^{\#}$ & $43.27 \pm 1.87$ & $2620 \pm 53$ & $2.87 \pm 0.011$ \\
\hline $\mathrm{K}_{2} \mathrm{HPO}_{4}$ & $2.37 \pm 0.01$ & $0.949 \pm 0.063$ & $2.21 \pm 0.026$ & $9.72 \pm 0.087^{\#}$ & $5.88 \pm 0.121$ & $28.18 \pm 1.26$ & $44.05 \pm 2.06$ & $2094 \pm 27^{\#}$ & $2.63 \pm 0.012$ \\
\hline $\mathrm{KH}_{2} \mathrm{PO}_{4}$ & $2.41 \pm 0.21$ & $0.917 \pm 0.04$ & $2.75 \pm 0.014$ & $10.26 \pm 0.124^{\#}$ & $4.40 \pm 0.98$ & $33.85 \pm 1.068$ & $42.87 \pm 1.17$ & $2691 \pm 38.65$ & $2.54 \pm 0.011$ \\
\hline $\mathrm{FeSO}_{4}$ & $2.93 \pm 0.022$ & $1.10 \pm 0.025$ & $2.70 \pm 0.11$ & $8.31 \pm 0.107$ & $5.36 \pm 1.03$ & $40.17 \pm 2.97$ & $38.86 \pm 2.37$ & $2713 \pm 29$ & $1.87 \pm 0.076^{\#}$ \\
\hline $\mathrm{MnSO}_{4}$ & $2.10 \pm 0.14^{\#}$ & $0.931 \pm 0.04^{\#}$ & $2.17 \pm 0.023$ & $9.48 \pm 0.98^{\#}$ & $5.51 \pm 1.21$ & $29.5 \pm 1.27^{\#}$ & $35.54 \pm 1.42$ & $2285 \pm 23^{\#}$ & $1.56 \pm 0.011^{\#}$ \\
\hline $\mathrm{ZnCl}_{2}$ & $1.71 \pm 0.023^{\#}$ & $0.089 \pm 0.02^{\#}$ & $1.16 \pm 0.07^{\#}$ & $8.40 \pm 0.031$ & $2.35 \pm 0.28$ & $31.15 \pm 0.243^{\#}$ & $34.23 \pm 0.86^{\#}$ & $1987 \pm 21^{\#}$ & $1.42 \pm 0.06^{\#}$ \\
\hline $\mathrm{KCl}$ & $1.95 \pm 0.012^{\#}$ & $0.618 \pm 0.031^{\#}$ & $2.40 \pm 0.11$ & $8.36 \pm 0.067$ & $4.95 \pm 0.56$ & $20.72 \pm 0.87^{\#}$ & $38.86 \pm 1.57$ & $2485 \pm 35$ & $2.89 \pm 0.013$ \\
\hline Control & $2.64 \pm 0.016$ & $1.30 \pm 0.03$ & $2.46 \pm 0.07$ & $8.29 \pm 0.083$ & $3.37 \pm 0.014$ & $40.85 \pm 1.63$ & $41.26 \pm 0.85$ & $2612 \pm 44$ & $3.07 \pm 0.016$ \\
\hline \multicolumn{10}{|l|}{ Nitrogen sources } \\
\hline $\begin{array}{l}\text { Ammonium } \\
\text { sulphate }\end{array}$ & $2.07 \pm 0.012$ & $0.446 \pm 0.03$ & $2.20 \pm 0.014^{*}$ & $11.5 \pm 0.086^{*}$ & $3.18 \pm 0.024$ & $24.62 \pm 2.03$ & $33.04 \pm 1.4^{*}$ & $2944.5 \pm 22.58$ & $1.83 \pm 0.014$ \\
\hline Sodium nitrate & $2.64 \pm 0.012^{*}$ & $0.920 \pm 0.04$ & $2.18 \pm 0.012^{*}$ & $11.81 \pm 0.065^{*}$ & $4.23 \pm 0.042$ & $25.63 \pm 1.86$ & $29.42 \pm 1.26$ & $1220 \pm 12.36$ & $1.27 \pm 0.018$ \\
\hline $\begin{array}{l}\text { Ammonium } \\
\text { chloride }\end{array}$ & $1.57 \pm 0.026$ & $0.731 \pm 0.03$ & $1.96 \pm 0.028$ & $12.26 \pm 0.102$ & $3.08 \pm 0.028$ & $22.9 \pm 1.74$ & $35.49 \pm 2.04^{*}$ & $3949 \pm 56.75$ & $0.86 \pm 0.02$ \\
\hline Urea & $2.07 \pm 0.014$ & $0.589 \pm 0.02$ & $1.72 \pm 0.016$ & $7.98 \pm 0.27$ & $2.79 \pm 0.014$ & $24.25 \pm 1.05$ & $30.29 \pm 2.85$ & $2807 \pm 23.37^{*}$ & $1.13 \pm 0.017$ \\
\hline Peptone & $3.14 \pm 0.060^{*}$ & $1.22 \pm 0.01$ & $2.25 \pm 0.023^{*}$ & $11.04 \pm 0.104$ & $4.13 \pm 0.033$ & $37.25 \pm 1.24$ & $45.23 \pm 1.22^{*}$ & $2692 \pm 28.45^{*}$ & $2.13 \pm 0.011$ \\
\hline Yeast extract & $2.83 \pm 0.02^{*}$ & $0.993 \pm 0.01$ & $1.30 \pm 0.067$ & $8.53 \pm 0.47^{*}$ & $1.80 \pm 0.04$ & $32.65 \pm 0.68$ & $37.75 \pm 1.06^{*}$ & $2834 \pm 18.78^{*}$ & $1.75 \pm 0.02$ \\
\hline CSL & $3.79 \pm 0.018$ & $1.25 \pm 0.012$ & $3.76 \pm 0.028$ & $14.72 \pm 0.56$ & $7.72 \pm 0.05$ & $40.08 \pm 2.02^{*}$ & $42.27 \pm 2.84^{*}$ & $2740 \pm 37.9^{*}$ & $3.17 \pm 0.011^{*}$ \\
\hline Soyabean meal & $1.65 \pm 0.012$ & $1.26 \pm 0.016$ & $2.07 \pm 0.014^{*}$ & $11.09 \pm 0.42$ & $4.67 \pm 0.058$ & $22.65 \pm 1.28$ & $37.24 \pm 1.06^{*}$ & $2932 \pm 25.87$ & $1.83 \pm 0.012$ \\
\hline Control & $2.88 \pm 0.035$ & $1.56 \pm 0.011$ & $2.81 \pm 0.022$ & $10.86 \pm 0.078$ & $5.23 \pm 0.034$ & $42.23 \pm 1.02$ & $41.27 \pm 2.03$ & $2663 \pm 31.66$ & $3.26 \pm 0.014$ \\
\hline
\end{tabular}

In case of carbon and nitrogen sources, all the values differ from the control significantly $(\mathrm{p}<0.001)$ by Dunnett's Multiple Comparison Test except those marked with* In case of metal salts all the values marked with\# differ from the control significantly $(p<0.001)$ by Dunnett's Multiple Comparison Test

\section{Effect of incubation temperature}

As observed in Table 2 incubation temperature was found to have a profound effect on enzyme yields. No FPase, glucoamylase and alginate lyase activity was observed at $20{ }^{\circ} \mathrm{C}$. However, production of all the enzymes was observed at $25{ }^{\circ} \mathrm{C}$. Further rise in temperature led to an increase in the enzyme yields and maximum activities of all the enzymes in the cocktail was observed at $30{ }^{\circ} \mathrm{C}$ except xylanase, which was found to be maximum at $35{ }^{\circ} \mathrm{C}$. Further rise in incubation temperature, lowered the enzyme yields. 


\section{Effect of initial $\mathrm{pH}$ of media}

To study the effect of $\mathrm{pH}$ on enzyme productivities of the cocktail, the initial $\mathrm{pH}$ of the media was varied from 2.0 to 10.0 and incubation was done at $30{ }^{\circ} \mathrm{C}$ for 6 days. Enzyme productivities were observed over a broad $\mathrm{pH}$ range. With an increase in $\mathrm{pH}$ from 2.0 to 4.0, the enzyme productivities also increased. Maximum CMCase, FPase, $\beta$-glucosidase, glucoamylase, mannanase and $\alpha$-amylase productions were observed at $\mathrm{pH} 4.0$ and maximum pectinase yield was at $\mathrm{pH}$ 5.0. Xylanase and alginate lyase activities were maximum at $\mathrm{pH}$ 7.0. The results are shown in Table 2.

\section{Standardization of biofilm formation}

Out of the different media used for biofilm standardization, $\mathrm{LB}$ and $\mathrm{BHI}$ were found to support maximum biofilm production by $E$. coli and $S$. Typhi respectively but there was no significant difference in biofilm produced with the use of these two media. In case of $S$. aureus, TSB was found to be the best for biofilm formation, respectively (Additional file 1: Fig. S2a). Further, maximum biofilm formation was observed after $72 \mathrm{~h}$ of incubation in case of $E$. coli and $S$. aureus while for $S$. Typhi maximum biofilm formation was observed after $48 \mathrm{~h}$ of incubation (Additional file 1: Fig. S2b) and further increase in incubation time led to a decrease in biofilm biomass.

\section{Biofilm removal efficiency of the enzyme cocktail}

The enzyme cocktail produced by the fungal isolate was found to eradicate the biofilms of the selected pathogens. However, the enzyme cocktail was found to be more effective against the Gram-negative bacteria i.e. E. coli and $S$. Typhi wherein $82.64 \pm 5.0 \%$ and $90.23 \pm 4.0 \%$ eradication was observed respectively. In the case of $S$. aureus $76.32 \pm 5.0 \%$ reduction was observed (Fig. 2).

\section{FESEM analysis}

To further investigate our results, FESEM analysis of biofilms, both enzyme treated and untreated, was performed. As shown in the Fig. 3, intact biofilm architecture with confluent growth of the cells was observed in the control biofilm (untreated), while in case of the enzyme treated biofilms, the biofilm architecture was completely lost and significant disruption of the biofilms was observed. However, the morphology of the cells, after biofilm disruption, was not affected but the density of the cells was significantly reduced as compared to the control or untreated biofilms.

\section{Removal of slime from KDP}

The efficacy of the multiple carbohydrases was tested to degrade/disperse thick slime layer developed on the inner surface of KDP. The effect of the enzymes was clearly visible within initial $2 \mathrm{~h}$ wherein clear dispersion of the slime was observed (Fig. 4), while no effect was observed on slime present on the control KDP as well as those treated with PBS and heat inactivated enzyme preparation. Further clearance of the slime was observed after $24 \mathrm{~h}$ wherein, a significant difference as compared to the control, PBS treated and heat inactivated enzymes could be observed. The action of enzymes continued till $48 \mathrm{~h}$ and a marked clearance of the slime was observed as compared to the controls.

\section{Discussion}

Looking at the heterogeneous nature of the polysaccharides present in the biofilms and the complexity of these polysaccharides due to inter-species and intra-species interactions of microorganisms in biofilms, a fungal strain capable of producing multiple carbohydrases including cellulases, hemicellulases, pectinase, amylases and alginate lyase was isolated. Following isolation, we tried to develop an economically viable medium for maximal co-production of all the enzymes.

After repeated screening, we were able to isolate a fungal strain S-34 that elaborated the required enzyme cocktail in appreciable amounts. The isolate was found to be closely related to Aspergillus niger and was named A. niger APS. This genus is considered as a model for enzyme production, as it is a source of various commercially important enzymes. Out of the different fermentation techniques tried for enzyme, surface fermentation was found to be the best. Since, the aim of the study was to develop an economically viable media for the coproduction of enzymes, this was a favourable finding as surface fermentation is easy to implement and control as compared to submerged and solid state fermentation. The equipment required is simple and there is no need of aeration or agitation of the fermentation broth which makes the whole fermentation process economical, in addition to the easy recovery of the product ultimately (Shah et al. 1991).

Evaluation of time course studies is of paramount importance for the production of enzymes from fungi. In the present study, optimum levels of different enzymes were found to be produced at different time intervals. The highest levels of different enzymes were achieved between 4 to 8 days, beyond which a gradual decrease in the enzyme(s) level was observed which was probably due to change in the $\mathrm{pH}$ or due to release of proteases or some inhibitory metabolites during the stationary phase. In addition, repression effect due to the accumulation of products of various enzymatic reactions might also result in decreased enzyme production (Chugh et al. 2016). Earlier, maximum concurrent production of various 
Table 2 Effect of environmental factors on co-production of various enzymes by A. niger APS

\begin{tabular}{|c|c|c|c|c|c|c|c|c|c|}
\hline \multirow[t]{2}{*}{ Factor } & CMCase & FPase & $\beta$-Glucosidase & Pectinase & Mannanase & Xylanase & $\begin{array}{l}\text { Gluco- } \\
\text { amylase }\end{array}$ & a-Amylase & $\begin{array}{l}\text { Alginate } \\
\text { lyase }\end{array}$ \\
\hline & \multicolumn{9}{|c|}{ Enzyme activity (IU/ml) } \\
\hline \multicolumn{10}{|c|}{ Incubation temperature $\left({ }^{\circ} \mathrm{C}\right)$} \\
\hline 20 & $1.44 \pm 0.017$ & 0.0 & $0.17 \pm 0.04$ & $4.5 \pm 0.98$ & $0.70 \pm 0.003$ & $11.33 \pm 1.78$ & 0.0 & $614.9 \pm 5.58$ & 0.0 \\
\hline 25 & $2.45 \pm 0.014$ & $0.86 \pm 0.024$ & $0.84 \pm 0.038$ & $6.55 \pm 0.106$ & $2.08 \pm 0.014$ & $28.48 \pm 0.31$ & $18.42 \pm 2.04$ & $2392.3 \pm 21.68$ & $1.23 \pm 0.04$ \\
\hline 30 & $3.84 \pm 0.012$ & $1.21 \pm 0.04$ & $3.62 \pm 0.028$ & $14.55 \pm 0.15$ & $7.33 \pm 1.07$ & $39.48 \pm 1.32$ & $42.31 \pm 2.56$ & $2774 \pm 2.67$ & $3.32 \pm 0.016$ \\
\hline 35 & $2.26 \pm 0.012$ & $0.49 \pm 0.026$ & $1.95 \pm 0.011$ & $10.75 \pm 0.304$ & $3.04 \pm 0.028$ & $41.14 \pm 1.04$ & $41.87 \pm 3.84$ & $2073 \pm 18.9$ & $2.72 \pm 0.016$ \\
\hline 40 & $2.37 \pm 0.014$ & $0.35 \pm 0.06$ & $1.85 \pm 0.078$ & $5.96 \pm 0.098$ & $2.39 \pm 0.018$ & $30.39 \pm 1.86$ & $36.42 \pm 2.03$ & $1182 \pm 12.32$ & $1.87 \pm 0.011$ \\
\hline 50 & $0.37 \pm 0.002$ & 0.0 & 0.0 & 0.0 & $0.47 \pm 0.01$ & 0.0 & 0.0 & 0.0 & 0.0 \\
\hline \multicolumn{10}{|l|}{ Initial pH } \\
\hline 2.0 & $0.27 \pm 0.06$ & $0.31 \pm 0.02$ & 0.0 & $4.87 \pm 0.068$ & $0.38 \pm 0.04$ & $23.12 \pm 2.14$ & 0.0 & $433.3 \pm 6.45$ & 0.0 \\
\hline 3.0 & $2.67 \pm 0.014$ & $0.53 \pm 0.042$ & $2.51 \pm 0.012$ & $8.35 \pm 0.22$ & $6.30 \pm 1.08$ & $31.04 \pm 2.86$ & $37.11 \pm 3.14$ & $2005.5 \pm 23.25$ & $1.26 \pm 0.011$ \\
\hline 4.0 & $3.85 \pm 0.014$ & $1.24 \pm 0.04$ & $3.72 \pm 0.20$ & $13.92 \pm 0.18$ & $7.58 \pm 0.98$ & $41.58 \pm 1.12$ & $39.10 \pm 4.48$ & $2759.6 \pm 30.62$ & $3.26 \pm 0.032$ \\
\hline 5.0 & $3.13 \pm 0.012$ & $1.02 \pm 0.023$ & $3.40 \pm 0.012$ & $14.26 \pm 0.12$ & $6.67 \pm 0.23$ & $41.82 \pm 1.56$ & $37.55 \pm 2.28$ & $2629.7 \pm 35.56$ & $3.53 \pm 0.028$ \\
\hline 6.0 & $2.44 \pm 0.014$ & $0.98 \pm 0.012$ & $2.63 \pm 0.025$ & $13.34 \pm 0.046$ & $4.28 \pm 0.067$ & $42.05 \pm 0.067$ & $36.31 \pm 1.13$ & $2428.9 \pm 27.45$ & $4.48 \pm 0.06$ \\
\hline 7.0 & $2.51 \pm 0.018$ & $0.92 \pm 0.01$ & $1.66 \pm 0.015$ & $6.14 \pm 0.86$ & $4.46 \pm 0.42$ & $48.41 \pm 2.13$ & $11.72 \pm 1.86$ & $2302.3 \pm 20.45$ & $4.73 \pm 0.07$ \\
\hline 8.0 & $2.23 \pm 0.014$ & $0.89 \pm 0.06$ & $1.69 \pm 0.011$ & $5.67 \pm 0.042$ & $4.26 \pm 0.045$ & $48.02 \pm 1.12$ & $10.86 \pm 1.12$ & $2236.7 \pm 24.37$ & $3.52 \pm 0.011$ \\
\hline 9.0 & $2.17 \pm 0.016$ & $0.77 \pm 0.03$ & $1.39 \pm 0.012$ & $5.37 \pm 0.37$ & $3.52 \pm 0.014$ & $44.84 \pm 3.86$ & $9.87 \pm 0.09$ & $2214.7 \pm 36.78$ & $1.72 \pm 0.017$ \\
\hline 10.0 & $2.17 \pm 0.011$ & $0.73 \pm 0.03$ & $0.83 \pm 0.011$ & $4.51 \pm 0.021$ & $3.12 \pm 0.012$ & $42.43 \pm 1.07$ & $2.59 \pm 0.15$ & $2104.6 \pm 27.42$ & $1.12 \pm 0.06$ \\
\hline
\end{tabular}

carbohydrases has been reported between 4-6 days of incubation from Aspergillus niger using rice straw, wheat bran (Kang et al. 2004) and deoiled rice bran (Chugh et al. 2016) as substrate.

Production of carbohydrases is inducible and strongly influenced (induced or repressed) by the carbon sources. In the past, various lignocellulosic substrates including wheat bran, deoiled rice bran, rice straw, wheat straw, corn stover and sugar cane bagasse etc. have been screened for various enzyme productions (Singh et al. 2014; Imran et al. 2017). In the present study, presence of diverse carbohydrates both in the kitchen waste and wheat bran might have induced the production of various carbohydrases by the isolate $A$. niger APS). In addition, high water binding capacity and high porosity of wheat bran allows easy penetration of the fungal hyphae and has been reported to induce variety of carbohydrases (Palmarola-Adrados et al. 2005; Jain and Agrawal 2018). The cellobiohydrolase ( $\mathrm{CBH})$ system in fungi like Aspergillus has been reported to be induced by cellulose, xylose and lactose. On the contrary, $\mathrm{CBH}$ system has been reported to be repressed in the presence of the glucose and other easily metabolizable sugars due to carbon catabolite repression (CCR) effect. Alginate lyase production has also been reported to be influenced by the type of carbon source present in the environment (Fu et al. 2008). Likewise, production of other carbohydrases including hemicellulases, pectinase and amylases is also inducible and wheat bran has been indicated to be a good inducer of these enzymes (Teixeira et al. 2000; Martínez-Trujillo et al. 2009; Irfan et al. 2012; Singh et al.
2014; Tallapragada and Venkatesh 2011), thereby indicating that the fungus can sense the availability of various carbohydrates in the environment and make the endogenous alterations to utilize those by production of various carbohydrases for its own benefit. In the study, effect of different metal salts was also studied and different enzymes were found to be induced maximally by different metal ions which are essential for the growth of fungi as they act as cofactors for various enzymes. Metal ions like phosphorus and sulphur are important constituents of nucleic acid and amino acids respectively.

In addition to carbon sources and metal salts, nitrogen sources (both organic and inorganic) have been found to induce hydrolytic enzymes. In this study, CSL was found to have a profound effect on production of various carbohydrases. CSL (a rich source of soluble proteins and amino acids) consists of dry matter $(50 \pm 2.31 \%)$, crude proteins $(40 \pm 2.1 \%)$, ash $(10 \pm 0.43 \%)$, nitrogen free extract $(16 \pm 1.10 \%)$ and lactic acid $(21 \pm 1.22 \%)$ (Nisa et al. 2006). Various studies support the use of organic nitrogen sources like peptone, yeast extract, urea, casein, soyabean meal etc. for the production of carbohydrases (Gautam et al. 2011; Deswal et al. 2011). Improved pectinase yields have also been reported using ammonium salts (Galiotou-Panayotou et al. 1997; Fawole and Odunfa, 2003). Peptone, $\mathrm{KNO}_{3}$ and yeast extract have been found to stimulate alginate lyase production (Sugano et al. 1995; Fu et al. 2008). Role of supplements like nitrogen sources becomes very critical in production of multienzymes as not many supplements enhance simultaneous production of all enzymes in a single bioreactor. 


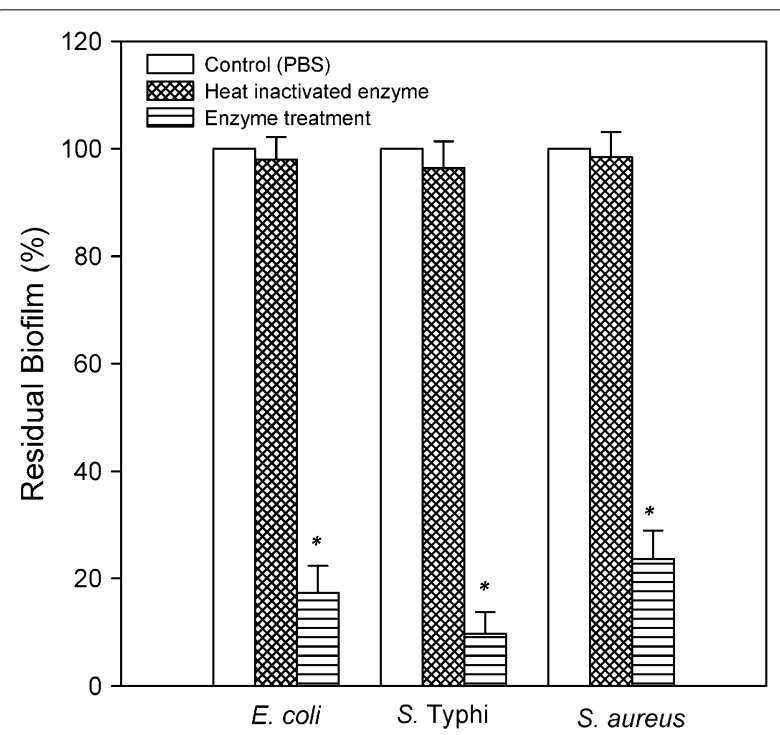

Fig. 2 Residual biofilm (\%) after treatment with in-house produced enzyme cocktail. * represents $p<0.0001$ versus control

Studies on the effect of supplementation of different carbon and nitrogen supplements show that not all sources act as enhancers for simultaneous production of these enzymes in a single fermentation system (Negi and Banerjee 2010). In the present study, certain nitrogen sources might have modified the $\mathrm{pH}$ of the substrate which in turn influenced the growth of $A$. niger APS and therefore, the enzyme yields or some inhibitory component in the complex nitrogen sources might had resulted in the decreased enzyme yields. It has been reported that nitrogen sources like ammonium are taken up in antiport with one proton, due to which there is a substantial acidification of the medium (Bhanja et al. 2007). This acidification causes growth to stop and results in inactivation of enzymes.

Optimum production of all the enzymes in the cocktail was achieved at incubation temperature of $30{ }^{\circ} \mathrm{C}$ except xylanase, which was found to be maximum at $35^{\circ} \mathrm{C}$. The optimum temperature for carbohydrase production varies with the strain, however a range between 25 and $30^{\circ} \mathrm{C}$ has been found to be optimum for various fungi (Ja'afaru and Fagade 2010; Gautam et al. 2011) and the optimum temperature for enzyme production depends on whether the culture is thermophilic or mesophilic. Enzyme production varies with the fungal growth and $30{ }^{\circ} \mathrm{C}$ has been reported to be optimum for growth of many fungi including $A$. niger. Higher temperatures (above $30{ }^{\circ} \mathrm{C}$ ) have been found to cause cell death as the cell membrane composition is altered and protein catabolism is also stimulated (Bansal et al. 2012). Maximum amylase yields from $A$. oryzae were reported at an incubation temperature of $30{ }^{\circ} \mathrm{C}$ (Sivaramakrishnan et al. 2007; Puri et al. 2013). Apart from the factors discussed, there is also a critical relation between initial $\mathrm{pH}$, fungal growth and enzyme production. $\mathrm{pH}$ plays a vital role in the structural modifications of the enzymes' active site, glycosylation of the enzymes and transport of molecules and enzymes across the membrane. Although the optimal growth and enzyme production varies from species to species but in case of fungi, the optimal $\mathrm{pH}$ range lies from 3.0 to 5.5 (Puri et al. 2013; Chugh et al. 2016). In the present study, the optima for production of different enzymes varied and majority of the enzymes were found to be produced optimally at acidic $\mathrm{pH}$. The results are in corroboration with earlier studies wherein high yields of cellulases from Trichoderma reesei Rut C-30, xylanase from A. niger and T. viridae, mannanase from Sclerotium rolfsii and $A$. terreus were achieved when $\mathrm{pH}$ of the medium was 4.0-4.5, 5.5, 5.0 and 6.0 (Großwindhager et al. 1999; Xiong et al. 2004; Liu et al. 2006; Soliman et al. 2012). Similar to our studies, neutral and alkaline $\mathrm{pH}$ have been found to favour alginate lyase production (Fu et al. 2008). Although, there are reports on multiple enzyme production by different fungi using submerged fermentation and solid state fermentation (Table 3), however, to the best of our knowledge this is the first study wherein production of cocktail of nine different enzymes from a single strain using surface fermentation has been reported and further, the activities of most of the enzymes are better than reported in the literature.

Biofilms pose a serious clinical, industrial as well as environmental challenge because of their recalcitrant nature. Therefore, it is crucial to either prevent biofilm formation or to eradicate/disperse preformed biofilms to prevent biofouling. In this context, the EPS of the biofilm can be targeted and looking at the heterogeneity of the EPS, we evaluated the ability of in-house produced enzyme cocktail produced by the isolated strain $A$. niger APS in biofilm removal. To study the effect of in-house produced enzymes on biofilm eradication, biofilms of different pathogens were developed on microtitre plate. Since the density of biofilm produced under in vitro conditions depends on medium composition and incubation period, these factors were standardised for the development of biofilms of selected pathogens. LB and BHI were found to support enhanced biofilm formation in E. coli and $S$. Typhi as compared to TSB. LB and BHI are nutrient rich media. Proteins rich in amino acids like leucine, proline, serine, and aspartate are present in BHI and these amino acids might play a role in the production of adhesions, necessary for adherence (Singh et al. 2017). Similarly, tryptone, yeast extract and dextrose present in LB make it a suitable medium for the growth of microorganisms. Further, sodium chloride present in LB helps 


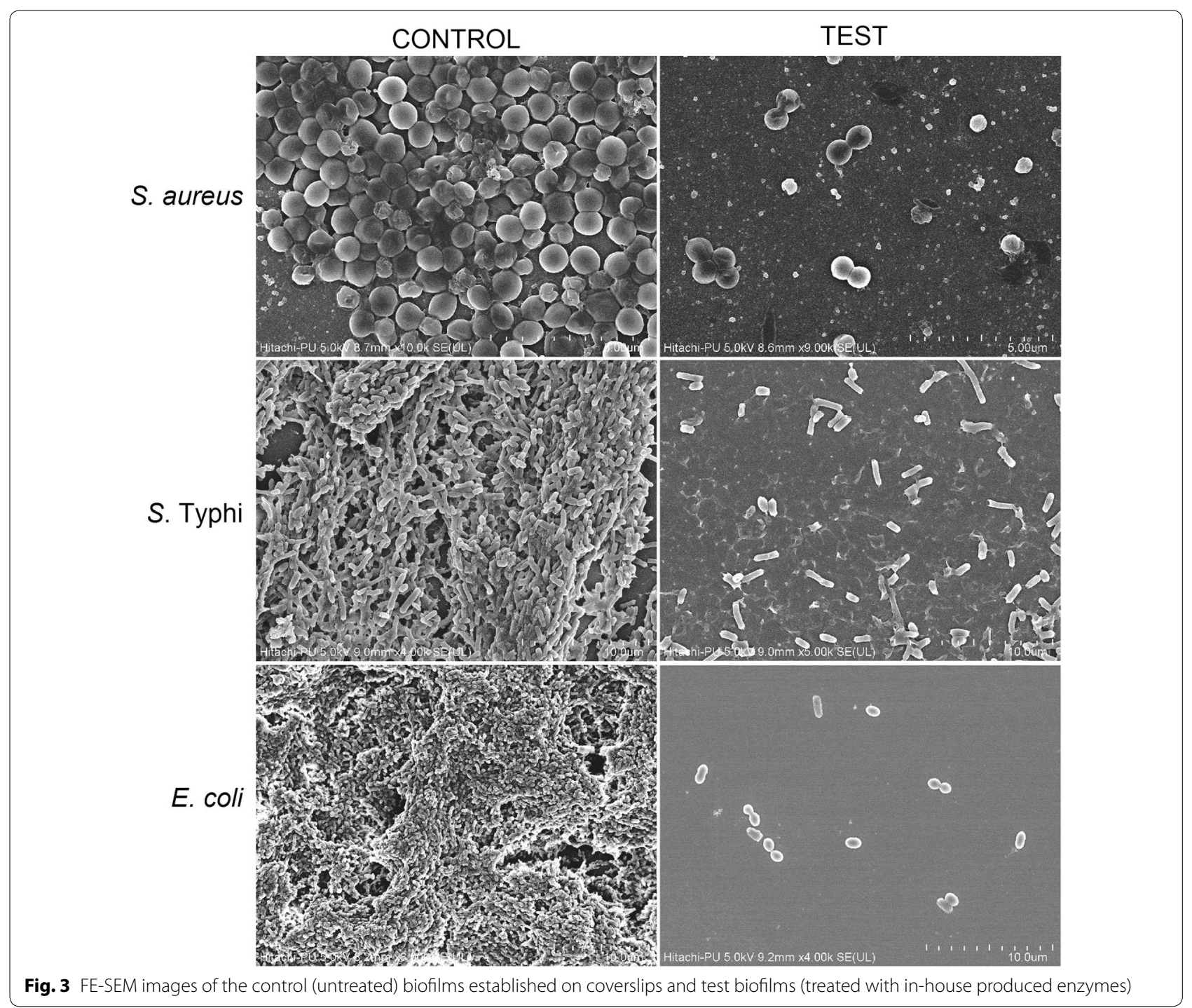

in the maintenance of proper isotonic environment of the broth, which further supports the growth of bacteria. In case of $S$. aureus, higher biofilm formation was supported by TSB which contains glucose enzymatic digests of casein and soybean meal and is a rich source of amino acids and nitrogenous substances. S. aureus is unable to ferment sugars such as inositol/myoinositol present in BHI which has been reported to result in resistance in $\mathrm{pH}$ fall, which, in turn, may be needed for robust biofilm architecture (Singh et al. 2017).

The extracellular polymeric substances (EPS) exuded by the biofilms act as a cementing material of the biofilms that holds the bacteria together as a community in a biofilm (Limoli et al. 2017). The extracellular polysaccharides are the major component of the biofilms and have been reported to be composed of homo- and hetero-polysaccharides composed of monomers like glucose, fucose, mannose, galactose, fructose, mannuronic acid, glucoronic acid or pyruvate based complexes. The bonds between these monomeric saccharides give rise to a plethora of different polysaccharides like levans, polymannans, cellulose, dextrans, amylopectin and alginate (Flemming et al. 2007; Limoli et al. 2017). The enzymes in the cocktail were found to efficiently disrupt the biofilms of all the pathogens however, the enzyme cocktail was found to be more effective against the biofilms of Gram-negative pathogens as the percentage reduction was found to be higher as compared to the Gram-positive counterparts. This could be due to the hydrolysis of the capsular polysaccharides (produced by both Salmonella enterica serovar Typhi and E. coli) by the action of multiple carbohydrases present in the cocktail. 


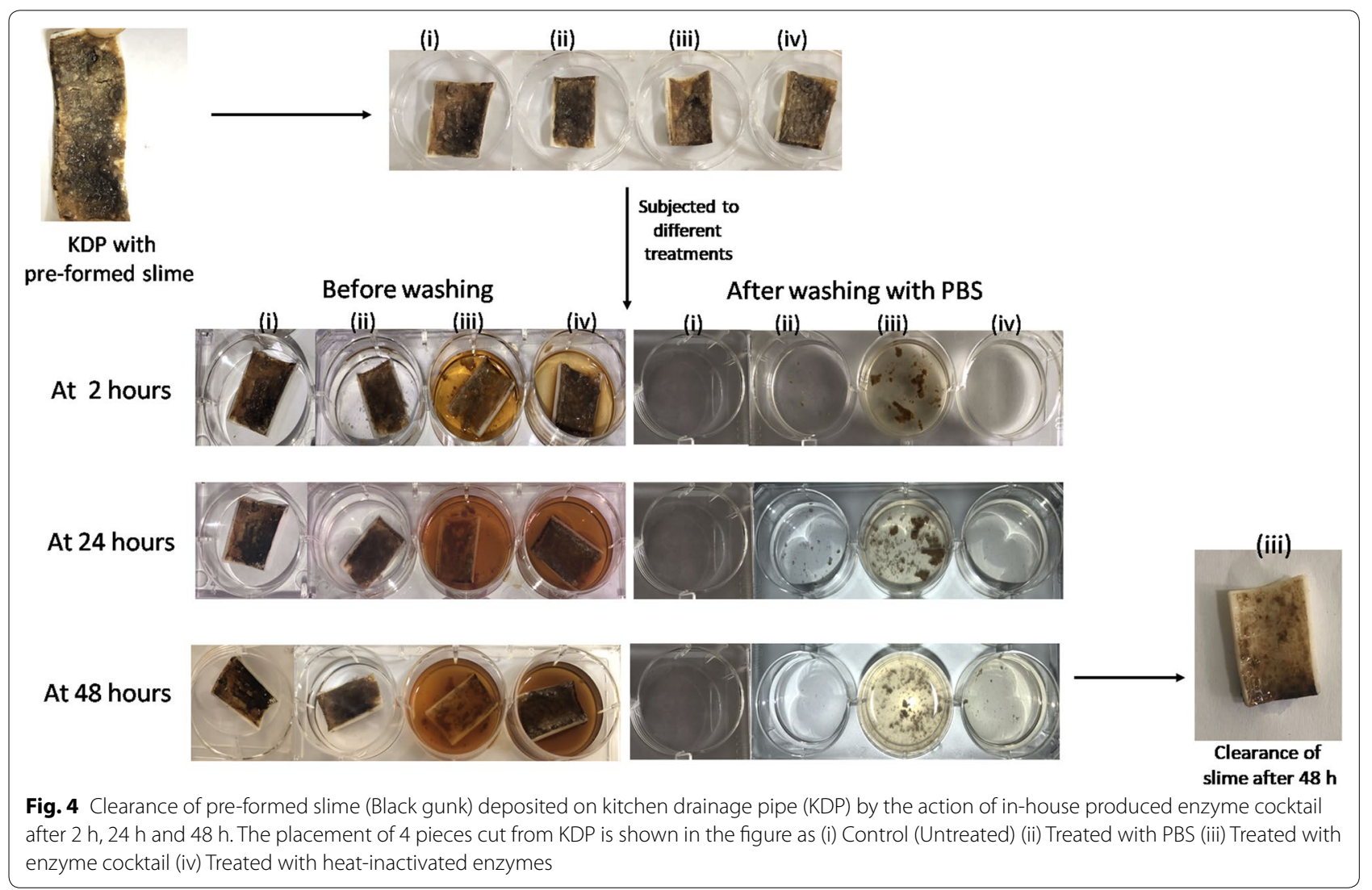

Various carbohydrases present in the cocktail might have degraded the polysaccharides present in the EPS leading to the loss of integrity of the EPS and finally resulted in the disruption of the biofilms which corroborated well with the morphological alterations observed in FESEM, wherein significant disruption of the biofilms was seen.

The significant clearance of the pre-formed slime layer on KDP might be due to the degradation of various polysaccharides present in the black gunk, as well as the ones produced by the microorganisms present in the biofilms, thus resulting in decreased viscosity and dispersion of the viscous slime layer. The clearance of the thick slime layer from KDP provides a promising insight for cleaning of drainage pipes, industrial pipelines and even sewerage systems. The clearance of slime formed on KDP is an interesting observation just giving the proof of concept. Only after executing studies pertaining to the concentration of enzyme cocktail and its appropriate formulation, the efficacy of enzyme cocktail can be compared with the commercially available agents. It may be noted that at this stage, it is not being claimed to be better than the commercially available agents but it may be another ecofriendly option to the chemical agents. Thus, the application of enzymes for the dispersal of biofilms and cleaning of slime would provide an interesting anti-biofouling alternative, especially in situations when the classical treatments involving chemical agents do not give satisfactory results.

Having an inclination towards process development using green technology, we have earlier reported the production of enzymatic cocktails from fungi (isolated from natural surroundings) followed by their application in diverse fields (Bansal et al. 2012; Janveja et al. 2013; Chugh et al. 2016; Rastogi et al. 2016). However, this is the first study wherein we have reported the concurrent production of a cocktail of nine different carbohydrases including alginate lyase from yet another natural variant of Aspergillus niger pertinent (i) for the successful dispersal of biofilms consisting of heterogeneous matrix, and (ii) for the removal of viscous slime layer from drainage pipe formed under natural conditions. This application holds a bright avenue to take care of manual scavenging which was banned in India in 1993 under the passing of the 'Employment of Manual Scavengers and Construction of Dry Latrines (Prohibition) Act, 1993'. The law was extended and clarified to include insanitary latrines, ditches and pits in 2013 in India under the 'Prohibition of Employment as Manual Scavengers and their Rehabilitation Act, 


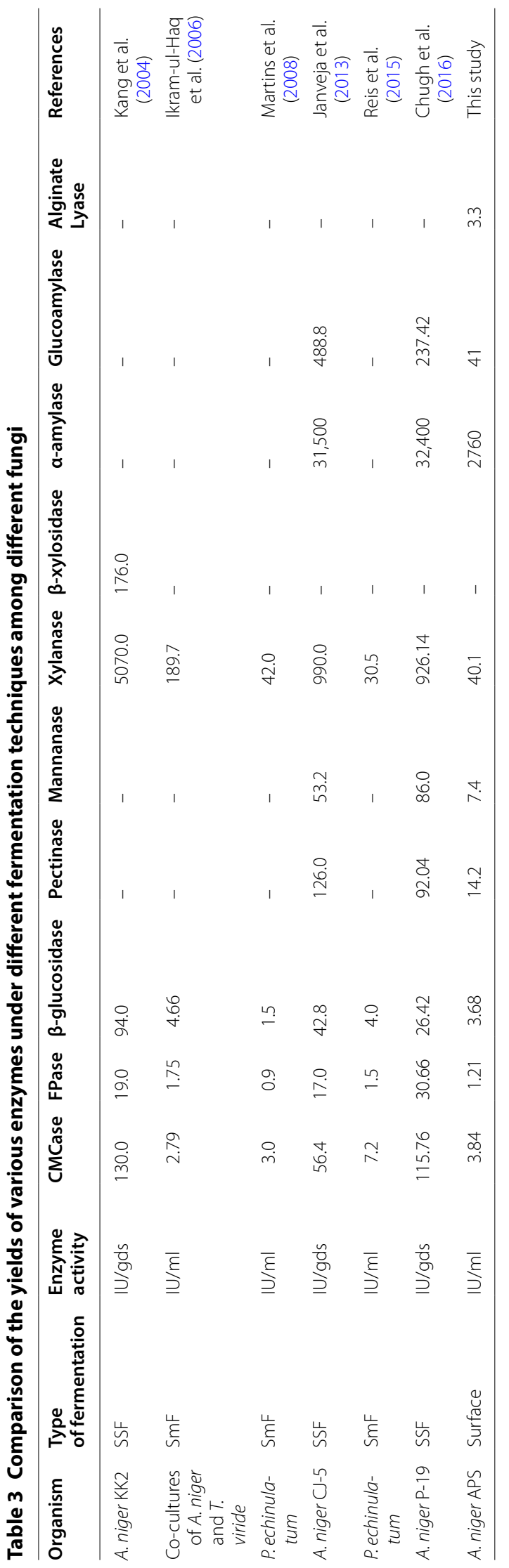




\section{The application of enzymes for cleaning drainage pipes might help to achieve this target in toto.}

\section{Supplementary information}

Supplementary information accompanies this paper at https://doi. org/10.1186/s13568-020-00970-3.

Additional file 1: Fig. S1. Time course study for co-production of different enzyme components a) Cellulases; b) Hemicellulases; c) Pectinase and alginate lyase; d) Amylases; over a period of 10 days (240 h) under submerged fermentation. Fig. S2. Standardization of biofilm formation a) Effect of different media (Luria broth LB, Brain Heart Infusion Broth BHI, Tryptic Soy broth TSB) on biofilm formation b) Effect of incubation period.

\section{Abbreviations}

ATCC: American Type Culture Collection; BLAST: Basic local alignment search tool; Bp: Base pair; CMCase: Carboxymethylcellulase; CSL: Corn steep liquor; EPS: Extracellular polymeric substance; FESEM: Field emission scanning electron microscopy; FPase: Filter paperase; ITS: Internal transcribed spacer; IU: International units; KDP: Kitchen drainage pipe; MTCC: Microbial Type Culture Collection; NCBI: National Center for Biotechnology Information; OVAT: One variable at a time; PBS: Phosphate Buffered Saline; PDA: Potato dextrose agar; SmF: Submerged fermentation; SSF: Solid state fermentation; rpm: revolutions per minute.

\section{Acknowledgements}

The authors acknowledge Sophisticated Analytical Instrumentation Facility (SAIF)/Central Instrumentation Laboratory, Panjab University, Chandigarh, India, for providing assistance in Field emission scanning electron microscopic (FESEM) analysis.

\section{Authors' contributions}

SKS and PR conceived and designed the study. AK performed the experiments. SKS, PR, AK and VR analyzed the data. AK and VR drafted the manuscript. SKS and PR read and approved the final manuscript. All authors read and approved the final manuscript.

\section{Funding}

This work was supported by financial assistance provided by University Grants Commission (UGC), New Delhi, India, under UGC-SAP program. Author 1 (Arashdeep Kaur) received fellowship provided by UGC-BSR under Research Fellowship in Sciences for meritorious students (RFSMS) scheme (F.7-261/2009(BSR)).

\section{Availability of data and materials}

The authors confirm that the data supporting the conclusions is given within the article. Raw data is available with the corresponding authors and would be available on request.

\section{Ethical approval \\ Not applicable.}

\section{Consent for publication}

All authors agreed to the publication of data reported in this work.

\section{Competing interests}

The authors declare that they have no competing of interest.

\section{Author details}

${ }^{1}$ Department of Microbiology, Panjab University, Chandigarh, India. ${ }^{2}$ Department of Civil Engineering, National Institute of Technical Teachers'Training and Research, Chandigarh, India.

Received: 31 January 2020 Accepted: 5 February 2020 Published online: 21 February 2020

\section{References}

Alsersy H, Salem AZ, Borhami BE, Olivares J, Gado HM, Mariezcurrena MD, Yacuot MH, Kholif AE, El-Adawy M, Hernandez SR (2015) Effect of Mediterranean saltbush (Atriplex halimus) ensilaging with two developed enzyme cocktails on feed intake, nutrient digestibility and ruminal fermentation in sheep. Animal Sci J 86(1):51-58. https://doi.org/10.1111/asj.12247

Bansal N, Tewari R, Soni R, Soni SK (2012) Production of cellulases from Aspergillus niger NS-2 in solid state fermentation on agricultural and kitchen waste residues. Waste Manage 32(7):1341-1346. https://doi.org/10.1016/j. wasman.2012.03.006

Bhanja T, Rout S, Banerjee R, Bhattacharyya BC (2007) Comparative profiles of a-amylase production in conventional tray reactor and GROWTEK bioreactor. Bioprocess Biosyst Eng 30(5):369-376. https://doi.org/10.1007/ s00449-007-0133-0

Binod P, Gnansounou E, Sindhu R, Pandey A (2019) Enzymes for second generation biofuels: recent developments and future perspectives. Bioresour Technol Rep 5:317-325. https://doi.org/10.1016/j.biteb.2018.06.005

Chugh P, Soni R, Soni SK (2016) Deoiled rice bran: a substrate for coproduction of a consortium of hydrolytic enzymes by Aspergillus niger P-19. Waste Biomass Valori 7(3):513-525. https://doi.org/10.1007/s1264 9-015-9477-x

Costerton JW, Lewandowski Z, Caldwelld DE, Korber DR, Lappin Scott HM (1995) Microbial biofilms. Ann Rev Microbiol 49:711e45. https://doi. org/10.1146/annurev.mi.49.100195.003431

Deswal D, Khasa YP, Kuhad RC (2011) Optimization of cellulase production by a brown rot fungus Fomitopsis sp. RCK2010 under solid state fermentation. Bioresour Technol 102(10):6065-6072. https://doi.org/10.1016/j.biort ech.2011.03.032

Fawole OB, Odunfa SA (2003) Some factors affecting production of pectic enzymes by Aspergillus niger. Int Biodeter Biodegr 52(4):223-227. https:// doi.org/10.1016/S0964-8305(03)00094-5

Fleming D, Chahin L, Rumbaug K (2017) Glycoside hydrolases degrade polymicrobial bacterial biofilms in wounds. Antimicrob Agents Chemother 61(2):e01998-e02016. https://doi.org/10.1128/AAC.01998-16

Flemming HC, Neu TR, Wozniak DJ (2007) The EPS matrix: the "house of biofilm cells". J Bacteriol 189(22):7945-7957. https://doi.org/10.1128/JB.00858-07

Flemming HC, Wingender J, Szewzyk U, Steinberg P, Rice SA, Kjelleberg S (2016) Biofilms: an emergent form of bacterial life. Nat Rev Microbiol 14(9):563-575. https://doi.org/10.1038/nrmicro.2016.94

Fu X, Lin H, Kim SM (2008) Optimization of culturing condition and medium composition for the production of alginate lyase by a marine Vibrio sp. YKW-34. J Ocean Univ China 7(1):97-102. https://doi.org/10.1007/s1 180 2-008-0097-y

Fuwa $\mathrm{H}$ (1954) A new method for microdetermination of amylase activity by the use of amylose as the substrate. J Biochem 41(5):583-603

Galiotou-Panayotou M, Kapantai M, Kalantzi O (1997) Growth conditions of Aspergillus sp. ATHUM-3482 for polygalacturonase production. Appl Microbiol Biotechnol 47(4):425-429. https://doi.org/10.1007/s002530050 951

Gautam SP, Bundela PS, Pandey AK, Khan J, Awasthi MK, Sarsaiya S (2011) Optimization for the production of cellulase enzyme from municipal solid waste residue by two novel cellulolytic fungi. Biotechnol Res Int. https:// doi.org/10.4061/2011/810425

Großwindhager C, Sachslehner A, Nidetzky B, Haltrich D (1999) Endo- $\beta-1$, 4-D-mannanase is efficiently produced by Sclerotium (Athelia) rolfsii under derepressed conditions. J Biotechnol 67(2-3):189-203. https://doi. org/10.1016/S0168-1656(98)00176-X

Ikram-ul-Haq Javed MM, Khan TS (2006) An innovative approach for hyper production of cellulolytic and hemicellulolytic enzymes by consortium of A. niger and T. viride MSK-10. Afr J Biotechnol 5:609-614

Imran M, Anwar Z, Irshad M, Javid A, Hussain A, Ali S (2017) Optimization of cellulase production from a novel strain of Aspergillus tubingensis IMMIS2 through response surface methodology. Biocatal Agric Biotechnol 12:191-198. https://doi.org/10.1016/j.bcab.2017.10.005

Irfan M, Nadeem M, Syed Q (2012) Media optimization for amylase production in solid state fermentation of wheat bran by fungal strains. J Cell Mol Biol 10(1):55-64 
Ja'afaru MI, Fagade OE (2010) Optimization studies on cellulase enzyme production by an isolated strain of Aspergillus niger YL128. Afr J Microbiol Res 4(24):2635-2639

Jain L, Agrawal D (2018) Performance evaluation of fungal cellulases with dilute acid pretreated sugarcane bagasse: a robust bioprospecting strategy for biofuel enzymes. Renew Energy 115:978-988. https://doi. org/10.1016/j.renene.2017.09.021

Janveja C, Rana SS, Soni SK (2013) Environmentally acceptable management of kitchen waste residues by using them as substrates for the co-production of a cocktail of fungal carbohydrases. Int J Chem Env Eng Syst. 4:20-29

Kalpana BJ, Aarthy S, Pandian SK (2012) Antibiofilm activity of a-amylase from Bacillus subtilis S8-18 against biofilm forming human bacterial pathogens. Appl Biochem Biotechnol 167(6):1778-1794. https://doi.org/10.1007/ s12010-011-9526-2

Kang SW, Park YS, Lee JS, Hong SI, Kim SW (2004) Production of cellulases and hemicellulases by Aspergillus niger KK2 from lignocellulosic biomass. Bioresour Technol 91(2):153-156. https://doi.org/10.1016/S0960 -8524(03)00172-X

Kimura M (1980) A simple method for estimating evolutionary rates of base substitutions through comparative studies of nucleotide sequences. J Mol Evol 16(2):111-120. https://doi.org/10.1007/BF01731581

Lamppa JW, Griswold KE (2013) Alginate lyase exhibits catalysis-independent biofilm dispersion and antibiotic synergy. Antimicrob Agents Chemother 57(1):137-145. https://doi.org/10.1128/AAC.01789-12

Lequette $Y$, Boels G, Clarisse M, Faille C (2010) Using enzymes to remove biofilms of bacterial isolates sampled in the food-industry. Biofouling 26(4):421-431. https://doi.org/10.1080/08927011003699535

Limoli DH, Whitfield GB, Kitao T, Ivey ML, Davis MR, Grahl N, Hogan DA, Rahme LG, Howell PL, O'Toole GA, Goldberg JB (2017) Pseudomonas aeruginosa alginate overproduction promotes coexistence with Staphylococcus aureus in a model of cystic fibrosis respiratory infection. MBio 8(2):e00186-17. https://doi.org/10.1128/mBio.00186-17

Liu Youssef AS, El-Naggar MY, El Assar SA, Beltagy EA (2006) Optimization of cultural conditions for $\beta$-mannanase production by a local Aspergillus niger isolate. Int J Agric Biol 8(4):539-545

Loiselle M, Anderson KW (2003) The use of cellulase in inhibiting biofilm formation from organisms commonly found on medical implants. Biofouling 19(2):77-85. https://doi.org/10.1080/0892701021000030142

Martínez-Trujillo A, Aranda JS, Gómez-Sánchez C, Trejo-Aguilar B, AguilarOsorio G (2009) Constitutive and inducible pectinolytic enzymes from Aspergillus flavipes FP-500 and their modulation by $\mathrm{pH}$ and carbon source. Braz J Microbiol 40(1):40-47. https://doi.org/10.1590/S1517-8382200900 0100006

Martins LF, Kolling D, Camassola M, Dillon AJ, Ramos LP (2008) Comparison of Penicillium echinulatum and Trichoderma reesei cellulases in relation to their activity against various cellulosic substrates. Bioresour Technol 99:1417-1424. https://doi.org/10.1016/j.biortech.2007.01.060

Miller GL (1959) Use of dinitrosalicylic acid reagents for the determination of reducing sugar. Anal Chem 31:426-428. https://doi.org/10.1021/ac601 $47 \mathrm{a} 030$

Naganthran A, Masomian M, Rahman RN, Ali M, Nooh H (2017) Improving the efficiency of new automatic dishwashing detergent formulation by addition of thermostable lipase, protease and amylase. Molecules 22(9):1577. https://doi.org/10.3390/molecules22091577

Negi S, Banerjee R (2010) Optimization of culture parameters to enhance production of amylase and protease from Aspergillus awamori in a single fermentation. Afr J Biochem Res 4(3):73-80

Nigam P (2013) Microbial enzymes with special characteristics for biotechnological applications. Biomolecules 3(3):597-611. https://doi.org/10.3390/ biom3030597

Nijland R, Hall MJ, Burgess JG (2010) Dispersal of biofilms by secreted, matrix degrading, bacterial DNase. PLoS ONE 5(12):e15668-16. https://doi. org/10.1371/journal.pone.0015668

Nisa M, Khan MA, Sarwar M, Lee WS, Lee HJ, Ki KS, Ahn BS, Kim HS (2006) Influence of corn steep liquor on feeding value of urea treated wheat straw in buffaloes fed at restricted diets. Asian Aust J Anim Sci 19(11):1610-1616. https://doi.org/10.5713/ajas.2006.1610

Orgaz B, Kives J, Pedregosa AM, Monistrol IF, Laborda F, SanJosé ZC (2006) Bacterial biofilm removal using fungal enzymes. Enzyme Microb Technol 40(1):51-56. https://doi.org/10.1016/j.enzmictec.2005.10.037
Orgaz B, Neufeld RJ, SanJose C (2007) Single-step biofilm removal with delayed release encapsulated Pronase mixed with soluble enzymes. Enzyme Microb Technol 40(5):1045-1051. https://doi.org/10.1016/j.enzmi ctec.2006.08.003

Palmarola-Adrados B, Chotěborská P, Galbe M, Zacchi G (2005) Ethanol production from non-starch carbohydrates of wheat bran. Bioresource Technol 96(7):843-850. https://doi.org/10.1016/j.biortech.2004.07.004

Payne DE, Boles BR (2016) Emerging interactions between matrix components during biofilm development. Curr Genet 62(1):137-141. https://doi. org/10.1007/s00294-015-0527-5

Pitts B, Hamilton MA, Zelver N, Stewart PS (2003) A microtiter-plate screening method for biofilm disinfection and removal. J Microbiol Methods 54(2):269-276. https://doi.org/10.1016/S0167-7012(03)00034-4

Puri S, Arora M, Sarao L (2013) Production and optimization of amylase and glucoamylase using Aspergillus oryzae under solid state fermentation. Int J Res Pure Appl Microbiol 3:83-88

Rana SS, Janveja C, Soni SK (2013) Brewer's spent grain as a valuable substrate for low cost production of fungal cellulases by statistical modeling in solid state fermentation and generation of cellulosic ethanol. Int J Food Ferment Technol 3(1):41. https://doi.org/10.5958/j.2277-9396.3.1.004

Rastogi S, Soni R, Kaur J, Soni SK (2016) Unravelling the capability of Pyrenophora phaeocomes S-1 for the production of ligno-hemicellulolytic enzyme cocktail and simultaneous bio-delignification of rice straw for enhanced enzymatic saccharification. Bioresour Technol 222:458-469. https://doi.org/10.1016/j.biortech.2016.10.012

Reis LD, Ritter CE, Fontana RC, Camassola M, Dillon AJ (2015) Statistical optimization of mineral salt and urea concentration for cellulase and xylanase production by Penicillium echinulatum in submerged fermentation. Braz J Chem Eng 32(1):13-22. https://doi.org/10.1590/0104-6632.20150321s0 0003099

Sawabe T, Ezura Y, Kimura T (1992) Purification and characterization of an alginate lyase from marine Alteromonas sp. Nippon Suisan Gakkaishi 58:521-527

Shah NK, Ramamurthy V, Kothari RM (1991) Comparative profiles of fungal alpha amylase production by submerged and surface fermentation. Biotechnol Lett 13(5):361-364. https://doi.org/10.1007/BF01027683

Singh S, Singh S, Bali V, Sharma L, Mangla J (2014) Production of fungal amylases using cheap, readily available agriresidues, for potential application in textile industry. Biomed Res Int. https://doi.org/10.1155/2014/215748

Singh V, Verma N, Banerjee B, Vibha K, Haque S, Tripathi CK (2015) Enzymatic degradation of bacterial biofilms using Aspergillus clavatus MTCC 1323. Microbiology 84(1):59-64. https://doi.org/10.1134/S0026261715010130

Singh AK, Prakash P, Achra A, Singh GP, Das A, Singh RK (2017) Standardization and classification of in vitro biofilm formation by clinical isolates of Staphylococcus aureus. J Glob Infect Dis 9(3):93-101. https://doi. org/10.4103/jgid.jgid_91_16

Singh A, Kaur A, Yadav RD, Mahajan R (2019) An efficient eco-friendly approach for recycling of newspaper waste. 3 Biotech 9(2):51. https://doi. org/10.1007/s13205-019-1590-2

Sivaramakrishnan S, Gangadharan D, Nampoothiri KM, Soccol CR, Pandey A (2007) Alpha amylase production by Aspergillus oryzae employing solidstate fermentation. J Sci Ind Res 66:621-626

Soliman HM, Sherief AA, EL-Tanash AB (2012) Production of xylanase by Aspergillus niger and Trichoderma viride using some agriculture residues. Int J Agric Res 7(1):46-57. https://doi.org/10.3923/ijar/2012/46-57

Stepanović S, Vuković D, Dakić I, Savić B, Švabić-Vlahović M (2000) A modified microtiter-plate test for quantification of staphylococcal biofilm formation. J Microbiol Methods 40(2):175-179. https://doi.org/10.1016/S0167 $-7012(00) 00122-6$

Sugano Y, Nagae H, Inagaki K, Yamamoto T, Terada I, Yamazaki Y (1995) Production and characteristics of some new $\beta$-agarases from a marine bacterium, Vibrio sp. strain JT0107. J Ferment Bioengineer 79(6):549-554. https://doi.org/10.1016/0922-338X(95)94746-E

Tallapragada P, Venkatesh K (2011) Isolation, identification and optimization of xylanase enzyme produced by Aspergillus niger under submerged fermentation. J Microbiol Biotechnol Res 1(4):137-147

Teixeira MF, Lima Filho JL, Durán N (2000) Carbon sources effect on pectinase production from Aspergillus japonicus 586. Braz J Microbiol 31(4):286-290. https://doi.org/10.1590/S1517-83822000000400009 
Tufvesson P, Fu W, Jensen JS, Woodley JM (2010) Process considerations for the scale-up and implementation of biocatalysis. Food Bioprod Process 88(1):3-11. https://doi.org/10.1016/j.fbp.2010.01.003

Wang Y, Wang Y, Sun L, Grenier D, Yi L (2018) Streptococcus suis biofilm: regulation, drug-resistance mechanisms, and disinfection strategies. Appl Microbiol Biotechnol 102(21):9121-9129. https://doi.org/10.1007/s0025 3-018-9356-z

Xiong $\mathrm{H}$, von Weymarn N, Leisola M, Turunen O (2004) Influence of $\mathrm{pH}$ on the production of xylanases by Trichoderma reesei Rut C-30. Process Biochem 39(6):731-736. https://doi.org/10.1016/S0032-9592(03)00178-X

Ye X, Wang Y, Hopkins RC, Adams MW, Evans BR, Mielenz JR, Zhang YH (2009)

Spontaneous high-yield production of hydrogen from cellulosic materials and water catalyzed by enzyme cocktails. Chem Sus Chem 2(2):149-152. https://doi.org/10.1002/cssc.200900017

Zhang R, Neu TR, Blanchard V, Vera M, Sand W (2019) Biofilm dynamics and EPS production of a thermoacidophilic bioleaching archaeon. New Biotechnol 51:21-30. https://doi.org/10.1016/j.nbt.2019.02.002

\section{Publisher's Note}

Springer Nature remains neutral with regard to jurisdictional claims in published maps and institutional affiliations.

\section{Submit your manuscript to a SpringerOpen ${ }^{\odot}$ journal and benefit from:}

- Convenient online submission

- Rigorous peer review

- Open access: articles freely available online

- High visibility within the field

Retaining the copyright to your article

Submit your next manuscript at $\boldsymbol{\nabla}$ springeropen.com 